\title{
Postharvest quality maintenance of longan fruit by ultra violet-C incorporated with salicylic acid application
}

\author{
Sonthaya Suiubon', Suriyan Supapvanich², Surassawadee Promyou ${ }^{1 *}$ \\ ${ }^{1}$ Faculty of Natural Resources and Agro-Industry, Kasetsart University, Chalermprakiate Sakon Nakhon Province Campus, Chiangkhrua, \\ Muang, Sakon Nakhon 47000, Thailand, '2Department of Agricultural Education, Faculty of Industrial Education, King Mongkut's Institute of \\ Technology Ladkrabang, Chalongkrung Road, Ladkrabang, Bangkok 10520, Thailand
}

\section{A B S T R A C T}

\begin{abstract}
The purpose of this study was to investigate the effects of salicylic acid (SA) dips incorporated with ultra violet-C (UVC) irradiation on postharvest quality of longan fruit cv. 'Dor' during refrigerated storage at $10^{\circ} \mathrm{C}$. The longan fruit were dipped in SA solution at the concentration of $0,1.0,2.0$ and $3.0 \mathrm{mM}$ before irradiated with $6.6 \mathrm{~kJ} \mathrm{~m}^{-2} \mathrm{UVC}$. Physicochemical quality attributes including peel colour, taste attributes, fruit decay, sensorial qualities and bioactive compounds were monitored. SA dips incorporated with the UVC irradiation maintained the outer peel lightness $\left(L^{*}\right)$, total ascorbic acid (TAA) content and crispness score of flesh as well as lowered colour difference $\left(\Delta \mathrm{E}^{*}\right)$ value of outer peel and the reduction total antioxidant capacity (TAC) of the flesh during storage. All treatments did not affect the fruit taste attributes including total soluble solids (TSS), total acidity (TA) and TSS/TA ratio. The fruit dipped with 2.0 and 3.0 mM SA incorporated with the UVC irradiation effectively delayed the fruit decay as well as inhibited off-flavour. The fruit dipped with $2.0 \mathrm{mM}$ SA incorporated with UVC irradiation showed the highest acceptability score and also enhanced the activity of antioxidant enzymes such as ascorbic acid peroxidase (APX), superoxide dismutase (SOD) and catalase (CAT).
\end{abstract}

Keywords: Longan fruit; Ultra violet-C; Salicylic acid; Postharvest quality; Antioxidant enzymes

\section{INTRODUCTION}

Longan (Dimocarpus longan Lour.) is known as a nonclimacteric subtropical fruit native to China, Southeast Asia and Northeastern India. In Southeast Asia countries, longan is a commercially famous fruit and widely grown in Vietnam and north of Thailand (Nakason and Paull 1998; Whangchai et al., 2006). In Thailand, longan fruit is an important commercially fruit which is exported more than 415,000 tons per year (Anonymous, 2016). However, the rapid deterioration of the fruit after harvest involving pericarp browning, fruit rot and pulp breakdown is the main factor reducing its shelf-life and marketing value (Jiang et al., 2002; Duan et al., 2007). It is widely recognized that pericarp browning of longan fruit after harvest has mainly been attributed to oxidation of phenolic compounds and browning enzymes such as polyphenol oxidase, phenylalanine ammonia lyase and peroxidase (Jiang 1999; Duan et al., 2007; Cheng et al., 2009). Moreover, as containing high sugars and moisture content, rapid growth of yeasts and fungi after harvest results to fruit rot which is a main postharvest problem of longan fruit. To control pericarp browning and fruit decay in longan fruit, sulfur dioxide $\left(\mathrm{SO}_{2}\right)$ treatment has been recommended and commercially used. However, many countries have restricted the $\mathrm{SO}_{2}$ use in longan fruit and also reduced the minimum permitted $\mathrm{SO}_{2}$ residue level, due to allergenic symptoms (Wangchai et al., 2006). The alternative methods replacing $\mathrm{SO}_{2}$ use have been recommended and widely investigated such as the use of ozone (Kim et al., 1999), X-ray irradiation (Follett and Sanxter, 2000), nitric oxide treatment (Duan et al., 2007) and hydrochloric acid dip (Apai, 2010).

UVC irradiation is an potential alternative method maintaining postharvest quality, inhibiting diseases and delaying ripening process of fresh commodities (Promyou and Supapvanich 2012; Rivera-Pastrana et al., 2014; Bal and Kok 2009; Kim et al., 2010; Obande et al., 2011). It also enhances plant defense mechanisms involving inducing phytochemicals which positively correlates with

\footnotetext{
${ }^{*}$ Corresponding author:

Surassawadee Promyou, Faculty of Natural Resources and Agro-Industry, Kasetsart University, Chalermprakiate Sakon Nakhon Province Campus, Chiangkhrua, Muang, Sakon Nakhon 47000, Thailand. Tel: +66-42-725036, Fax: +66-42-725037. E-mail: csnsrwd@ku.ac.th
} 
the reduction deterioration and physiological disorders and resistance against pathogens (Obande et al., 2011; Rivera-Pastrana et al., 2014). Salicylic acid (SA) is known as a phytohormone inducing plant defense mechanisms under abiotic and biotic stress (Asghari and Aghdam 2010). The exogenous SA has been used to maintain postharvest quality, delay fruit ripening as well as enhance biologically active compounds, imparting health benefits (Srivastava and Dwivedi 2000; Zhang et al., 2003; Lu et al., 2011; Khademi and Ershadi 2013; Supapvanich 2015; Razavi et al., 2014). Moreover, SA is also claimed as a safe, natural compound used in postharvest processing of fruit (Supapvanich and Promyou 2013). However, the use of salicylic acid for fresh fruit and vegetable is limited to concentrations that are non-toxic to plants, with an optimum range of about 0.5-2 mM (Babalar et al., 2007). Thus, we were interested in the investigation of exogenous SA use incorporated with UVC irradiation for maintaining postharvest quality including pericarp browning and extending shelf-life of fresh longan fruit during refrigerated storage.

\section{MATERIALS AND METHODS}

\section{Raw materials preparation}

Longan (Dimocarpus longan Lour. cv. Dor) fruit at full maturity stage was harvested from a commercial orchard in Chiang Mai Province, Thailand. The fruits were separated into bunches without defect and individually selected for uniformity of shape size and peel colour, cleaned with tap water (at $25^{\circ} \mathrm{C}$ ) and dipped in $100 \mu \mathrm{L} \cdot \mathrm{L}^{-1}$ sodium hypochlorite to control fruit rot and allowed to air-dried before treatments. The fruits were randomly distributed into five groups for different treatment: (a) untreated fruit were used as control which did not receive SA and UVC; (b) exposed to UVC; (c); (d); and (e) treated with UVC incorporated with salicylic solution at 1.0, 2.0 and $3.0 \mathrm{mM}$, respectively. For each treatment, three replicates were used. Fruit were sampled at the initial day and at 2 day intervals.

\section{UVC incorporated with exogenous SA treatment}

The longan fruits were dipped in 1.0, 2.0 and $3.0 \mathrm{mM} \mathrm{SA}$ solution for $1 \mathrm{~h}$, and then air-dried at room temperature. After SA treatments, fruits were placed in a plastic box (1.32 $\mathrm{m}$ length, $1.85 \mathrm{~m}$ wide and $0.8 \mathrm{~m}$ deep) containing two germicidal UV lamps (TUV 30W, Salvania, Japan) and irradiated at a distance of $70 \mathrm{~cm}$ above and below fruit for 90 minutes to obtain the dosage of $6.6 \mathrm{~kJ} \mathrm{~m}^{-2}$. The dose of UVC light was measured using a UV light meter model UVC-580010 (Sper Scientific, USA). Then the treated fruits were randomly placed in perforated PVC bag and held at $10{ }^{\circ} \mathrm{C}$ in absence of light for 8 days. Longan fruit were inspected for superficial colour, total soluble solids (TSS), total titratable acidity (TA), fruit decay and taste.

Longan pulp was also collected for chemical analysis, using three replications per treatment. Each replication consisted of 60 randomly sampled fruit.

\section{Superficial colour}

Superficial colour measurement in outer and inner peel of longan fruits were measured on opposite side of the fruit using a Minolta (CR-300; Minolta Camera Co., Japan). Lightness $\left(L^{*}\right)$, hue angle and chroma values were recorded. Total colour difference $\left(\left(\Delta E^{*}\right)\right.$ of the fruit during storage compared to the initial day were calculated as $\Delta E^{*}=\sqrt{(\Delta L *)^{2}+\left(\Delta a^{*}\right)^{2}+\left(\Delta b^{*}\right)^{2}}$.

Total soluble solids (TSS), total titratable acidity (TA), fruit decay and taste

The taste of the longan fruit was indicated by measuring TSS, TA and TSS/TA ratio. Pulp from 60 fruits were homogenized using a Polytron PT 2100 (Kinematica AG, Switzerland) and then centrifuged at $15000 \mathrm{~g}$ for $15 \mathrm{~min}$. The supernatant phase was collected to analyse for TSS, using a hand refractometer (Milwaukee, China); total titratable acidity determined by tritation with $0.1 \mathrm{M}$ $\mathrm{NaOH}$. Fruit decay was determined by counting the fruit that observing visible fruit rot or fungal growth or bacterial lesions on the fruit surface expressed as percentage of fruit decay from three replications of the sixty-measured samples. The sensory attributes of the fruit was evaluated using nine points hedonic test by twenty-trained panelists for the overall acceptability and nine-points ranking test on crispness and off-flavor. A nine-points hedonic scale was used to determine the overall acceptance using the following scales: $9=$ like extremely, $5=$ neither like nor dislike, the limit of acceptance, and $1=$ dislike extremely.

\section{Total antioxidant capacity (TAC) and total ascorbic acid (TAA)}

The antioxidant capacity of the sample was determined using a ferric reducing antioxidant potential (FRAP) assay according to the method described by Benzie and Strain (1996). The FRAP reagent was a mixture of $25 \mathrm{~mL}$ acetate buffer $\mathrm{pH}$ 3.0, $2.5 \mathrm{~mL} 10 \mathrm{mM}$ 2,4,6-trioyridyl-1,3,5-triazine (TPTZ) and $2.5 \mathrm{~mL} 20 \mathrm{mM}$ ferric chloride hexahydrate. The mixture reaction was started when $0.5 \mathrm{~mL}$ of the supernatant added into $5 \mathrm{~mL}$ of FRAP solution. The reaction solution was incubated at ambient temperature for $30 \mathrm{~min}$ and then the absorbance was measured at $630 \mathrm{~nm}$. The antioxidant capacity was expressed as micro moles of Trolox equivalents per gram fresh weight ( $\mu$ mole Trolox equivalent/g FW). Ascorbic acid content (AsA) in the longan pulp was determined using 2,6-dichloroindophenol 
titrimetric method (AOAC, 1995). The data were expressed as $\mathrm{mg}$ ascorbic acid per $100 \mathrm{~g}$ of fresh weight (mg AsA/100 g FW)

\section{Antioxidant enzymes extraction and assay}

Antioxidant enzymes were extracted and assayed using a modification of the method by Chomkitichai et al. (2014). Two grams of longan pulp were homogenized in $20 \mathrm{~mL}$ of $30 \mathrm{mM}$ potassium phosphate buffer ( $\mathrm{pH} 7.8$ ) with addition $0.4 \mathrm{mM}$ EDTA, $1 \mathrm{mM}$ ascorbic acid and 1\% (w/v) polyvinyl polypyrrolidone (PVPP). The homogenized mixture was centrifuged at $15,000 \mathrm{~g}$ for $20 \mathrm{~min}$ at $4^{\circ} \mathrm{C}$ and the supernatant liquid was used as an enzyme extract for ascorbate peroxidase (APX), Superoxide dismutase (SOD) and Catalase (CAT).

APX activity, the assay reaction solution $(2.0 \mathrm{~mL}$ final volume) contained $0.5 \mathrm{~mL}$ of $100 \mathrm{mM}$ potassium phosphate buffer ( $\mathrm{pH} 7.0$ ), $0.5 \mathrm{~mL}$ of $1 \mathrm{mM}$ ascorbic acid, $0.5 \mathrm{~mL}$ of $0.4 \mathrm{mM}$ EDTA, $0.02 \mathrm{~mL}$ of $10 \mathrm{mM} \mathrm{H}_{2} \mathrm{O}_{2}$, $0.38 \mathrm{~mL}$ of distilled water and $0.1 \mathrm{~mL}$ of supernatant, the absorbance of the mixture was measured at $290 \mathrm{~nm}$. One unit of enzyme activity was defined as the increased of absorbance per min and per $\mathrm{mL}$ enzyme solution.

SOD activity, the assay reaction solution $(2.0 \mathrm{~mL}$ final volume) contained $0.8 \mathrm{~mL}$ of distilled water, $0.5 \mathrm{~mL}$ of $50 \mathrm{mM}$ potassium phosphate buffer ( $\mathrm{pH} 5.0$ ), $0.1 \mathrm{~mL}$ of $20 \mu \mathrm{M}$ nitroblue tetrazolium (NBT), $0.2 \mathrm{~mL}$ of $22 \mu \mathrm{M}$ methionine, $0.2 \mathrm{~mL}$ of $0.1 \mu \mathrm{M}$ Triton-X, $0.1 \mathrm{~mL}$ of $0.6 \mu \mathrm{M}$ riboflavin as an enzyme-substrate and $0.1 \mathrm{~mL}$ of supernatant, the absorbance of the mixture was measured at $560 \mathrm{~nm}$. One unit of enzyme activity was defined as quantity of enzyme that inhibited 50\% NBT photochemical-reduction.

CAT activity, the assay reaction solution $(2.0 \mathrm{~mL}$ final volume) contained $1.9 \mathrm{~mL}$ of $50 \mathrm{mM}$ potassium phosphate buffer ( $\mathrm{pH} 7.0$ ) plus $25 \mathrm{mM} \mathrm{H}_{2} \mathrm{O}_{2}$ and $0.1 \mathrm{~mL}$ of supernatant, the absorbance of the mixture was measured at $240 \mathrm{~nm}$ Activity of CAT enzyme was expressed as unit per $\mathrm{mg}$ protein. One unit of enzyme activity was defined as absorbance change in 0.01 unit $\mathrm{min}^{-1}$. In order to determined specific enzyme activity, the protein content was measured using the method described by Bradford (1976) using bovine serum albumin as a standard.

\section{Statistical analysis}

The experiment data were analyzed using a factorial with completed randomized design and three replicates \pm standard error (S.E.). Analysis of variance (ANOVA) was calculated and means separations were determined using Duncan's Multiple Range Tests (DMRT) at $P \leq 0.05$. All experiments were repeated once or twice at later dates.

\section{RESULTS AND DISCUSSION}

\section{Superficial colour of longan peel}

Superficial colour of longan fruit peel is a main factor affecting consumer's acceptability. Fig. 1 present the superficial colour attributes of both outer and inner of the fruit peel during storage at $10{ }^{\circ} \mathrm{C}$ for 8 days. SA dips incorporated with $6.6 \mathrm{~kJ} \mathrm{~m}^{-2} \mathrm{UVC}$ irradiation maintained the $L^{*}$ value (an indicator of browning) and $\Delta E^{*}$ value of the outer peel whilst a marked decrease in $L^{*}$ value and increase in $\Delta E^{*}$ value were found in the outer fruit peel irradiated with $6.6 \mathrm{~kJ} \mathrm{~m}^{-2}$ UVC and the untreated fruit. Similarly, a previous works of Promyou and Supapvanich (2012) who reported that UVC irradiation did not affect the change in $L^{*}$ value of 'Golden' bell pepper fruit and Supapvanich (2015) who found that the combination of SA and hot water dip lowered the rambutan fruit skin browning. Browning inhibitory effect of SA is associated with the enhancement of antioxidant and plant defense mechanism resulting in maintaining cell membrane integrity and reducing oxidation in tissues (Asghari and Aghdam 2010; Supapvanich and Promyou 2013). Other colour attributes of the outer longan fruit peel (hue and chroma values) and all colour attributes of the inner fruit peel of all treatments remained constant over storage and no significant difference of these colour attributes during storage were found. These reveal that SA dips incorporated with UVC irradiation at $6.6 \mathrm{~kJ} \mathrm{~m}^{-2}$ effectively inhibited the outer fruit peel darkening and maintained the fruit peel colour during storage.

\section{Total soluble solids (TSS), total acidity (TA) and TSS/TA ratio}

The taste of the longan fruit was indicated by measuring TSS, TA and TSS/TA ratio. As the results shown in Fig. 2, TSS and TA content of all treatments remained constant throughout storage which TSS and TA of the fruit were approximately $18{ }^{\circ}$ Brix and $0.18 \%$, respectively. TSS/TA ratio of the fruit was high and that of the fruit treated with SA dips incorporated with the UVC irradiation was slightly higher than that of the UVC treated and untreated fruits. Regarding to the high TSS and TSS/TA ratio and very low TA, sweet is the main taste attribute of the fruit and both UVC irradiation and SA dip incorporated with UVC irradiation did not affect the fruit taste over the storage. The results are concordance with previous works of González-Aguilar et al. (2001) who reported that sucrose content of 'Tommy Atkin' mango fruit irradiated with UVC for 10 min was similar to that of the untreated fruit over storage and Supapvanich (2015) who found that SA dips had no influence on taste quality attributes (TSS, TA and TSS/TA ratio) of rambutan fruit during refrigerated storage. Moreover, longan is known as a non-climacteric 


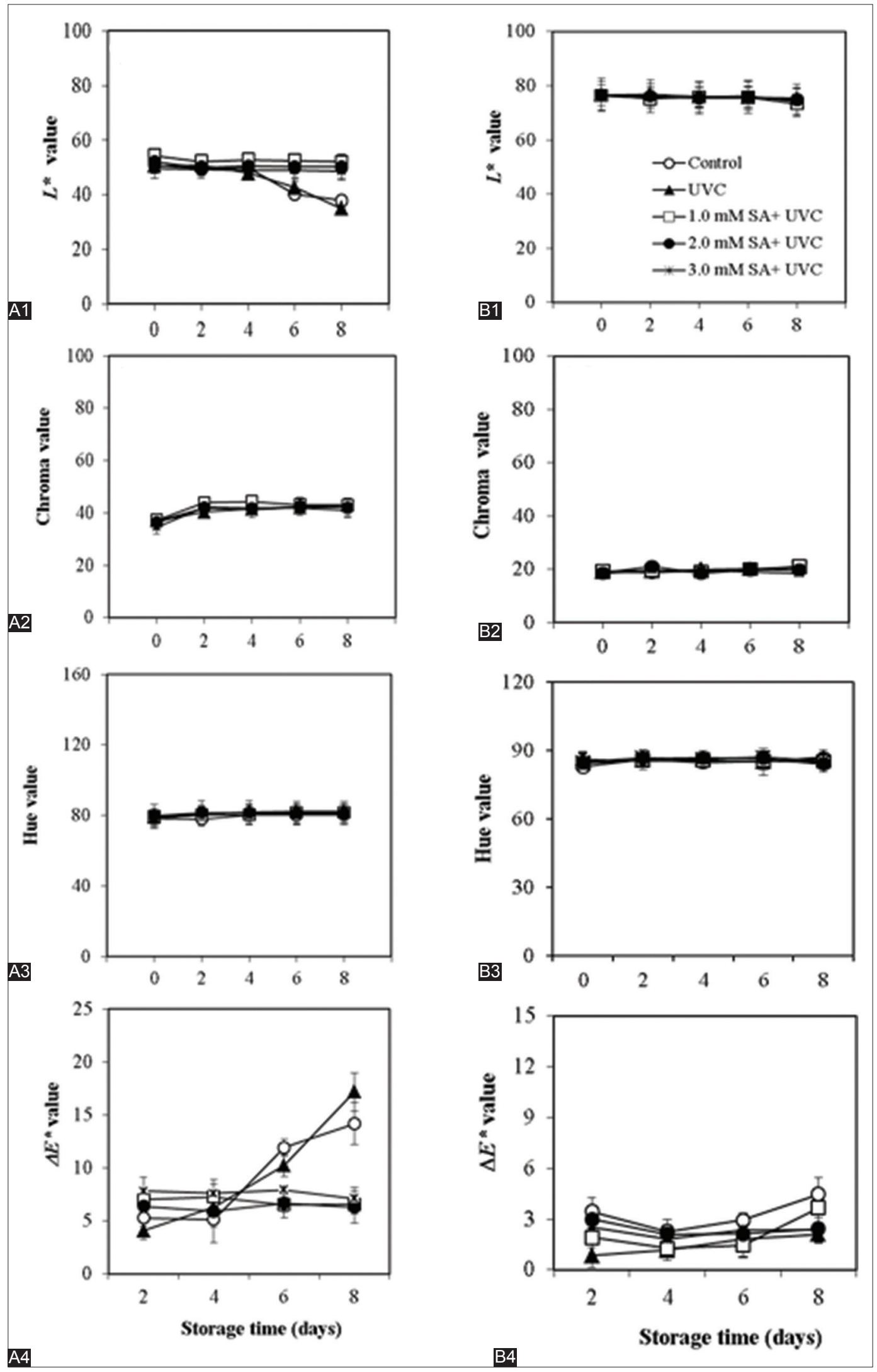

Fig 1. Outer (A) and inner (B) peel colour, $L^{*}(1)$, chroma value (2), hue value (3) and $D E^{*}$ value (4) of longan fruit treated with UVC and UVC incorporated with SA solutions during storage. Vertical bars represent the standard deviation of the means. 


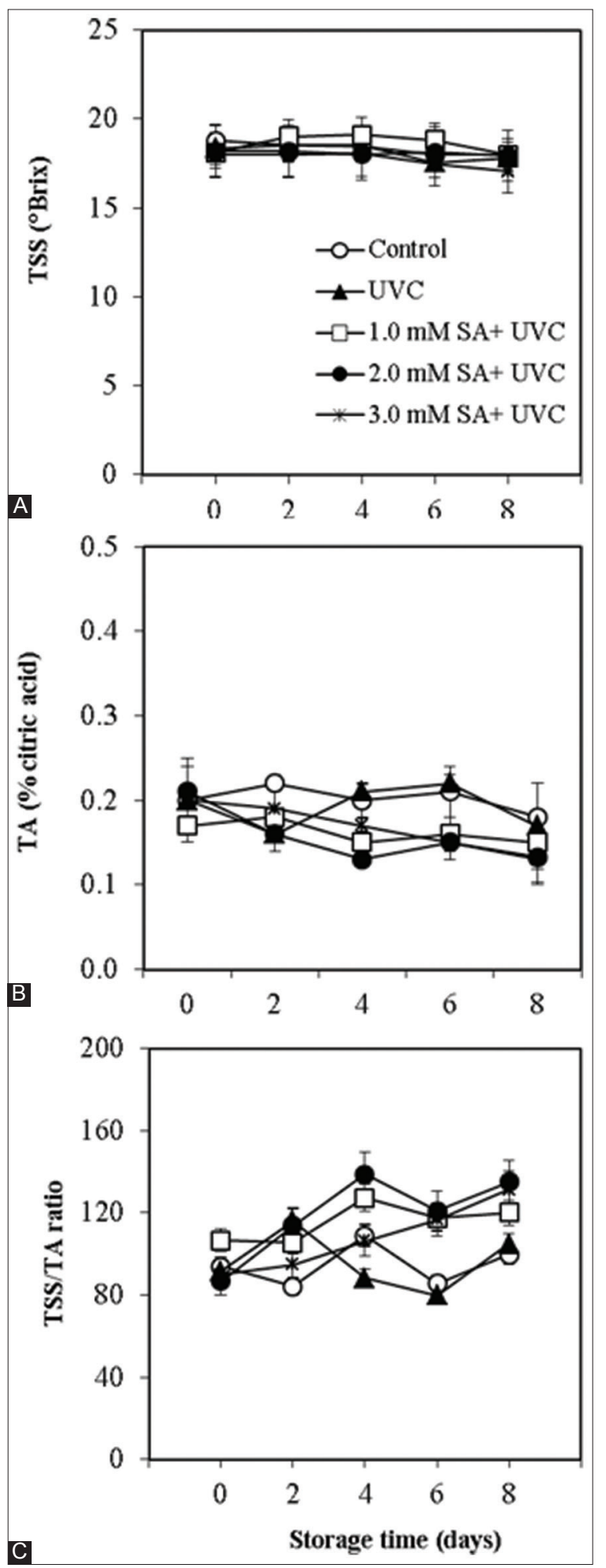

Fig 2. Total soluble solids (TSS) (A), total titratable acidity (TA) (B) and TSS/TA ratio (C) of longan fruit treated with UVC and UVC incorporated with SA solutions during storage. Vertical bars represent the standard deviation of the means.

fruit which harvested at commercial maturity (peak maturity). Thus, TSS and TA content of the fruit do not apparently change during postharvest period.

\section{Fruit decay and sensory evaluation}

Fig. 3 shows the percentage of fruit decay during storage and the sensory attributes involving overall preference, crispness and off-flavor scores of the longan fruit at the end of storage. The decay of the untreated fruit (control) was found on $2^{\text {nd }}$ day of storage and continuously increased during storage which the fruit decay reached to $15 \%$ at the end of storage. The decay of UVC irradiated fruit was detected on $6^{\text {th }}$ day of storage and then sharply increased which on day 8 , the decay of the fruit reached to $13.5 \%$. SA dips incorporated with the UVC irradiation potentially retarded the fruit decay during storage as shown in Fig. 3A. The potential of SA dip preventing the fruit decay relied on the concentration of SA which this study shows that SA dip at $2.0 \mathrm{mM}$ incorporated with $6.6 \mathrm{~kJ} \mathrm{~m}^{-2} \mathrm{UVC}$ irradiation effectively inhibited the decay of the longan fruit during storage. Whilst, $3.0 \mathrm{mM} \mathrm{SA}$ dip might harm to fruit skin tissues because of high SA concentration resulting in the decay occurrence on the $6^{\text {th }}$ day of storage. The results show that both UVC irradiation and SA dip delayed the longan fruit decay during storage and the combination of SA and UVC irradiation showed the synergistic effect. Terry and Joyce (2004) had described that UVC at low doses $(190-280 \mathrm{~nm})$ retards postharvest rots of fresh commodities by targeting the DNA of microorganisms. The induction of systemic disease resistance in fruit by exogenous SA application has been confirmed (Cai and Zheng 1999; Supapvanich and Promyou 2013). Malamy et al. (1990) addressed that SA has an anti-pathogenic function inducing resistance to the invading pathogens in fruit.

The sensory attributes of the fruit was evaluated using nine-points hedonic test for the overall acceptability and nine-points ranking test for crispness and off-flavor. The highest overall acceptability was detected on the fruit treated with $2.0 \mathrm{mM} \mathrm{SA}$ dip incorporated with the UVC irradiation and the lowest one was found in the control fruit. SA dips incorporated with the UVC irradiation maintained the crispness score of the fruit rather than the UVC irradiation alone and the untreated fruit, respectively. This shows that SA dip retarded the longan fruit softening during storage. The result was concordance with the previous works which reported that SA retarded the softening of kiwifruit (Zhang et al., 2003), sugar apple (Mo et al., 2008), peach (Khademi and Ershadi 2013) and rambutan (Supapvanich 2015). Srivastava and Dwivedi (2000) reported that cell wall hydrolases activities in banana fruit were inhibited by SA treatment resulting in delaying softening process. Furthermore, SA dips incorporated with the UVC irradiation inhibited off-flavor of the fruit over storage whilst a high off-flavor score was found in the untreated fruit which was approximately 7. 


\section{Total antioxidant capacity (TAC) and total ascorbic acid (TAA)}

Fig. 4 shows TAC and TAA content of the longan fruit pulp during storage. TAC content of the longan fruit of all treatments decreased during storage. TAC content of the control was lower than that of other treatment whilst that of $1.0 \mathrm{mM} \mathrm{SA}$ dips incorporated with UVC was higher than that of others during storage. TAC content of the UVC treated fruit remained constant for 4 days and then apparently decreased whilst that of SA dips incorporated with UVC treated fruit remained constant for 6 days and then also decreased (Fig. 4A). TAA content of the control decrease markedly throughout storage and was significantly lower than that of other treatment. A slight decrease in TAA content of UVC treated and SA dips incorporated with UVC treated fruits were found during storage for 6 days. After day 6 , that of the UVC treated fruit decreased apparently when compared with SA dips incorporated with
UVC treated fruit. The highest TAA content was found in the $2.0 \mathrm{mM}$ SA dip incorporated with UVC treated fruit. The results show that both UVC and SA dip incorporated with UVC treatments could maintain nutritional value and bioactive compounds of the longan fruit during storage. Similarly, many previous works reported that exogenous SA application induces the synthesis of bioactive compounds having antioxidant property and reduces the loss of ascorbic acid content in pomegranate (Sayyari et al., 2009), asparagus (Wei et al., 2011), peach (Razavi et al., 2014) and rambutan (Supapvanich, 2015). Supapvanich and Promyou (2013) addressed that UVC could induce defense mechanisms including enhancing bioactive compounds and antioxidant enzyme activities in plants. In the similar vein, enhanced bioactive compounds having antioxidant property by UVC application had been reported in tomato (Barka et al., 2000), strawberry (Erkan et al., 2008), and yellow bell pepper (Promyou and Supapvanich, 2012). In

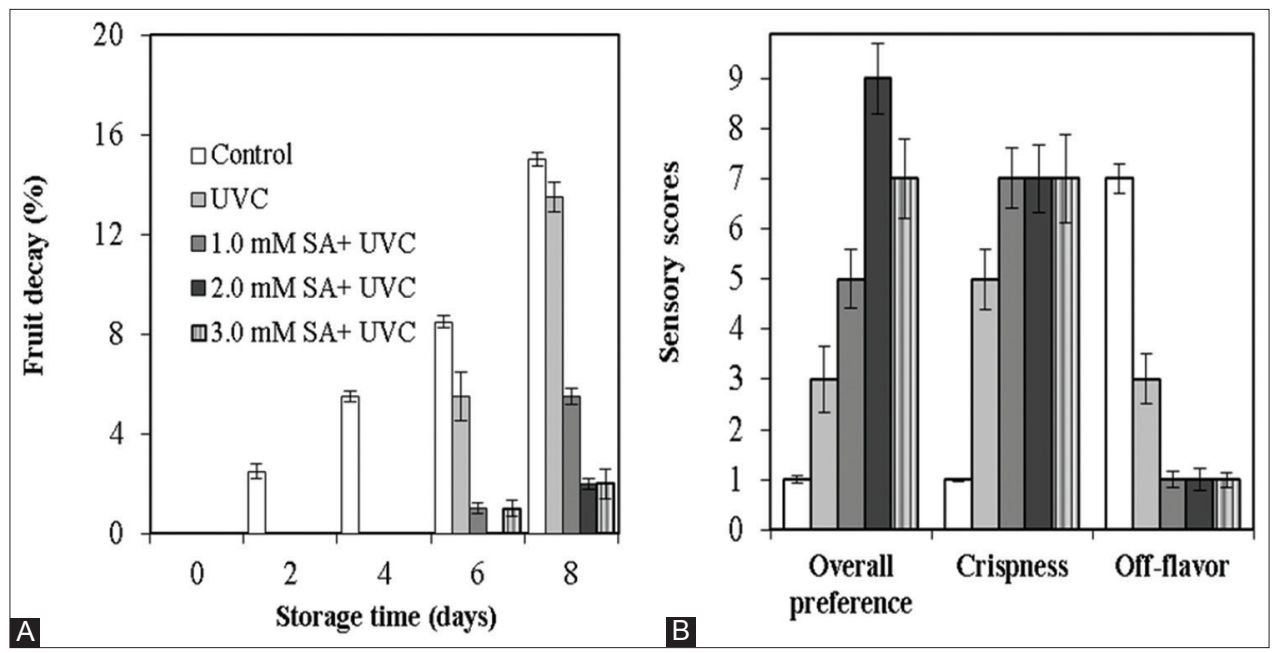

Fig 3. Fruit decay (\%) during storage (A) and sensory evaluation scores after storage for 8 days (B) of longan fruit treated with UVC and UVC incorporated with SA solutions. Vertical bars represent the standard deviation of the means.

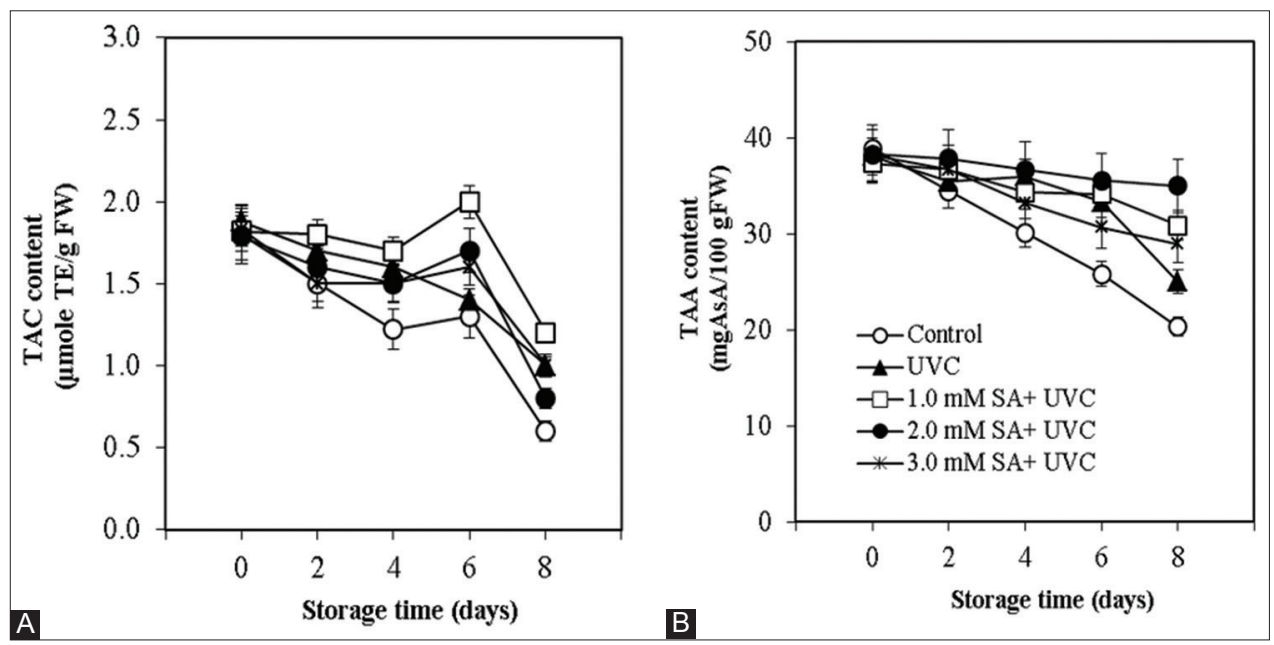

Fig 4. Total antioxidant capacity (TAC) (A) and total ascorbic acid (TAA) content (B) of longan fruit treated with UVC and UVC incorporated with $\mathrm{SA}$ solutions during storage. Vertical bars represent the standard deviation of the means. 
this work, we found that both TAC and TAA content of SA dips incorporated with UVC treated fruit were higher than those of UVC use alone. These might show a synergistic effect of UVC and SA in maintaining bioactive compounds of the longan fruit during storage.

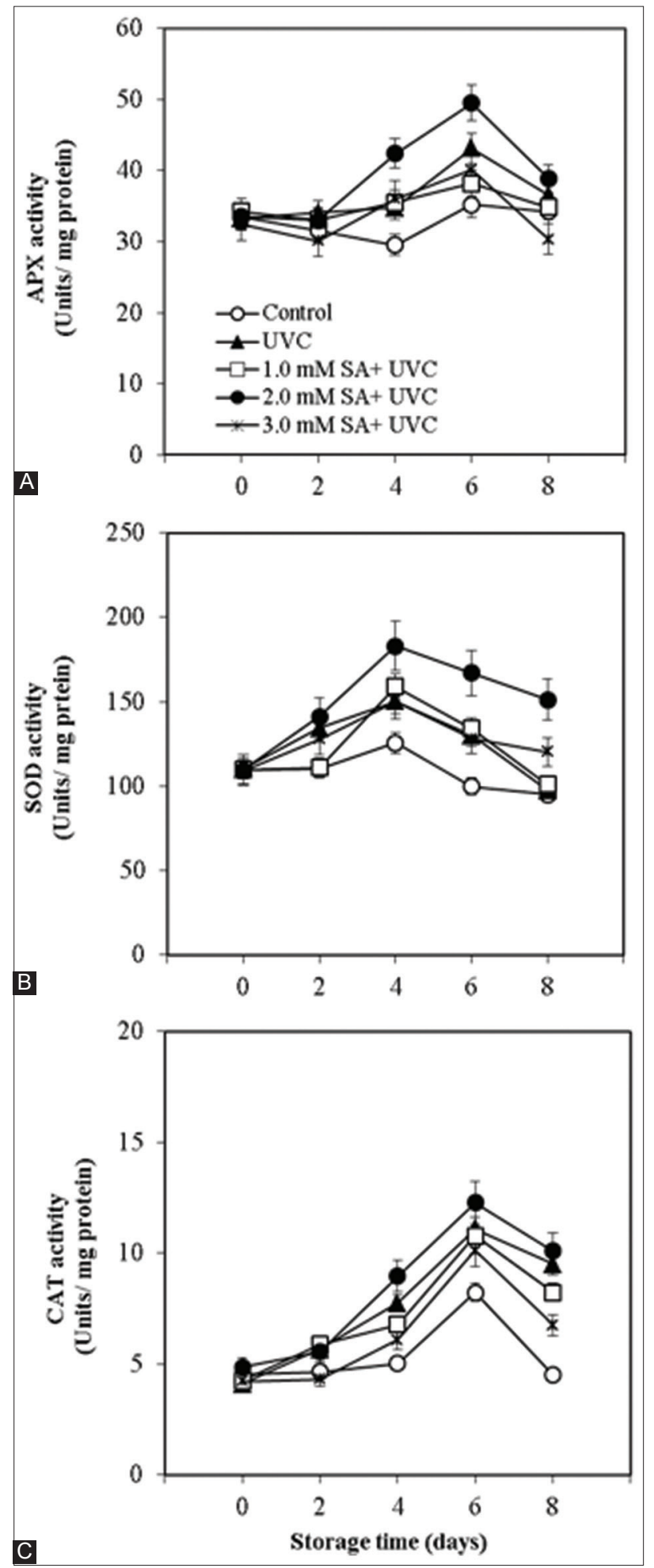

Fig 5. APX (A), SOD (B) and CAT (C) activities of longan fruit treated with UVC and UVC incorporated with SA solutions during storage. Vertical bars represent the standard deviation of the means.

\section{Antioxidant activity}

Fig. 5 shows that antioxidant enzymes including APX, SOD and CAT activities were enhanced by both UVC and UVC incorporated with SA treatments. The most antioxidant enzymes enhancement was found in the longan fruit treated with UVC incorporated with $2.0 \mathrm{mM} \mathrm{SA}$. After 2 days of storage, the activities of all antioxidant enzymes in the longan fruit treated UVC incorporated with $2.0 \mathrm{mM}$ SA obviously increased and higher than those of other treatments, whereas the lowest activities of all antioxidant enzymes were found in the untreated fruits throughout the storage. Compared to the UVC treatment only, it seemed that there was synergistic effect between UVC radiation and $2.0 \mathrm{mM} \mathrm{SA}$ dip on improving nutritional quality as enhanced activities of antioxidant enzymes and maintained TAA content (Fig. 4B). The results are supported by many previous works that exogenous SA application enhanced peroxidase, SOD and CAT activities in a range of fruits such as sweet cheery (Giménez et al., 2016), 'Cara cara' navel orange (Huang et al., 2008), cucumber (Zhang et al., 2011).

\section{CONCLUSIONS}

In conclusion, SA dips incorporated with UVC irradiation could control outer peel colour changes and fruit decay, maintain TAC and TAA contents and sensorial quality attributes including taste, off-flavour development and overall acceptability and enhance antioxidant enzymes activities including APX, SOD and CAT. All treatments had no influence on TSS, TA and TSS/TA ratio during storage. $2.0 \mathrm{mM}$ SA dip incorporated with UVC irradiation showed the best result controlling fruit decay during storage. Thus, we suggest that there is a synergistic effect between $2.0 \mathrm{mM}$ SA dip and UVC irradiation maintaining fresh-liked quality, preventing fruit decay and enhancing antioxidant enzymes activities of the longan fruits during refrigerated storage.

\section{ACKNOWLEDGMENTS}

This research is supported in part by the Graduate Program Scholarship from the Graduate School, Kasetsart University, Thailand and also the authors are grateful to Postharvest Technology Innovation Center, Commission on Higher Education, Bangkok, for providing grants.

\section{Author's contributions}

Surassawadee Promyou was the project director who planned the overall experiments, interpreted and analyzed data and wrote this article. Sonthaya Suiubon was the master degree student who operated all experiments, collected data and also analyzed some part of the experiments. Suriyan Supapvanich supervised certain scientific approaches and the project plan, interpreted data and wrote this article. 


\section{REFERENCES}

AOAC. 1995. Official Methods of Analysis, $16^{\text {th }}$ ed. Association of Official Analytical Chemists International, Washington, DC.

Anonymous. 2016. Total and Export Values of Agricultural Goods. Available from: http://www.oae.go.th/oae_report/export_import/ export.php. December 20, 2016.

Apai, W. 2010. Effects of fruit dipping in hydrochloric acid then rinsing in water on fruit decay and browning of longan fruit. Crop Prot. 29: 1184-1189.

Asghari, M. and M. S. Aghdam. 2010. Impact of salicylic acid on post-harvest physiology of horticultural crops. Trends Food Sci. Technol. 21: 502-509.

Babalar, M., M. Asghari, A. Talaei and A. Khosroshahi. 2007. Effect of pre- and postharvest salicylic acid treatment on ethylene production, fungal decay and overall quality of Selva. Food Chem. 105: 449-453.

Bal, E. and D. Kok. 2009. Effect of UV-C treatment on kiwifruit quality during the storage period. J. Cent. Eur. Agric. 10(4): 375-382.

Barka, E. A., S. Kalantari, J. Makhlouf and J. Arul. 2000. Impact of UV-C irradiation on the cell-wall degrading enzymes during ripening of tomato (Lycopersicon esculentum L.) fruit. J. Agric. Food Chem. 48: 667-671.

Benzie, I. F. F. and J. J. Strain. 1996. The ferric reducing ability of plasma (FRAP) as a measure of "antioxidant power": The FRAP assay. Anal. Biochem. 239: 70-76.

Bradford, M. M. 1976. A rapid and sensitive method for the quantitation of microgram quantities of protein utilizing the principle of protein-dye binding. Anal. Biochem. 72: 248-254.

Cai, X. Z. and Z. Zheng. 1999. Induction of systemic resistance in tomato by and incompatible race of Cladosporium fulvum and the accumulation dynamics of salicylic acid in tomato plants. Acta Hortic. Sin. 29: 261-264.

Cheng, G., Y. Jiang, X. Duan, A. Macnish, Y. You and Y. Li. 2009. Effect of oxygen concentration on the biochemical and chemical changes of stored longan fruit. J. Food Qual. 32: 2-17.

Chomkitichai, W., B. Faiyue, P. Rachtanapun, J. Uthaibutra and K. Saengnil. 2014. Enhancement of the antioxidant defense system of post-harvested 'Daw' longan fruit by chlorine dioxide fumigation. Sci. Hortic. 178: 138-144.

Duan, X., X. Xu, Y. You, H. Qu, Y. Li. and Y. Jiang. 2007. Effect of nitric oxide on pericarp browning of harvested longan fruit in relation to phenolic metabolism. Food Chem. 104: 571-576.

Erkan, M., S. Y. Wang and C. Y. Wang. 2008. Effect of UV treatment on antioxidant capacity, antioxidant enzyme activity and decay in strawberry fruit. Postharvest Biol. Technol. 48: 163-171.

Follett, P. A. and S. S. Sanxter. 2000. Comparison of rambutan quality after hot forced-air and irradiation quarantine treatments. Hortic Sci. 35: 1315-1318.

Giménez, M. J., M. Serrano, J. M. Valverde, D. Martínez-Romero, S. Castillo, D. Valero and F. Guillén. 2016. Preharvest salicylic acid and acetylsalicylic acid treatments preserve quality and enhance antioxidant systems during postharvest storage of sweet cherry cultivars. J. Sci. Food. Agric. Wileyonlinelibrary. com. DOI: 10.1002/jsfa.7853.

Gonzalez-Aguilar, G. A., C. Y. Wang, J. G. Buta and D. T. Krize. 2001. Use of UV-C irradiation to prevent decay and maintain postharvest quality of ripe 'Tommy Atkins' mangoes. Int. J. Food Sci. Technol. 36(7): 767-773.

Huang, R., R. Xia, Y. Lu, L. Hu, and Y. Xu. 2008. Effect of pre-harvest salicylic acid spray treatment on post-harvest antioxidant in the pulp and peel of 'Cara cara' navel orange (Citrus sinenisis L.
Osbeck). J. Sci. Food Agric. 88: 229-236.

Jiang, K., Z. Zhang, D. C. Joyce and S. Ketsa. 2002. Postharvest biology and handling of longan fruit (Dimocarpus longan Lour.). Postharvest Biol. Technol. 26: 241-252.

Jiang, Y. 1999. Purification and some properties of polyphenol oxidase of longan fruit. Food Chem. 66: 75-79.

Kim, J. Y., H. J. Kim, G. O. Lim, S. A. Jang and K. B. Song. 2010. The effects of aqueous chlorine dioxide or fumaric acid treatment combined with UV-C on postharvest quality of 'Maehyang' strawberries. Postharvest Biol. Technol. 56(3): 254-256.

Lu, X., D. Sun, Y. Li, W. Shi and G. Sun. 2011. Pre-and post-harvest salicylic acid treatments alleviate internal browning and maintain quality of winter pineapple fruit. Sci. Hortic. 130: 97-101.

Malamy, J., J. P. Carr, D. F. Klessig and I. Raskin. 1990. Salicylic acid: A likely endogenous signal in the resistance response of tobacco to viral infection. Science. 250(4983): 1002-1004.

Mo, Y., D. Gong, G. Liang, R. Han, J. Xie and W. Li. 2008. Enhanced preservation effects of sugar apple fruits by salicylic acid treatment during postharvest storage. J. Food Sci. 88(15): 2693-2699.

Nakason, H. Y. and R. E. Paull. 1998. Tropical Fruits, CAB International, Wallingford, UK.

Obande, M. A., G. A. Tucker and G. Shama. 2011. Effect of preharvest UV-C treatment of tomatoes (Salanum lycopersicon Mill.) on ripening and pathogen resistance. Postharvest Biol. Technol. 62(2): 188-192.

Promyou, S. and S. Supapvanich. 2012. Effect of ultraviolet-C (UV-C) illumination on postharvest quality and bioactive compounds in yellow bell pepper fruit (Capsicum annuum L.) during storage. Afr. J. Agric. Res. 7: 4084-4096.

Razavi, F., J. Hajilou, G. Dehgan, R. N. B. Hassani and M. Turchi. 2014. Enhancement of postharvest quality of peach fruit by salicylic acid treatment. Int. J. Biosci. 4(1): 177-184.

Rivera-Pastrana, D. M., A. A. Gardea, E. M. Yahia, M. A. Martinez-Tellez and G. A. Gonzalez-Aguilar. 2014. Effect of UV-C irradiation and low temperature storage on bioactive compounds, antioxidant enzymes and radical scavenging activity of papaya fruit. J. Food Sci. Technol. 51(12): 3821-3829.

Sayyari, M., M. Babalar, S. Kalantari, M. Serrano and D. Valero. 2009. Effect of salicylic acid treatment on reducing chilling injury in stored pomegranates. Postharvest Biol. Technol. 53: 152-154.

Srivastava, M. K. and U. N. Dwivedi. 2000. Delayed ripening of banana fruit by salicylic acid. Plant Sci. 158: 87-96.

Supapvanich, S. and S. Promyou. 2013. Efficiency of salicylic acid application on postharvest perishable crops. In: Hayat, S., A. Ahmad and M. N. Alyemeni, (Eds.), Salicylic Acid: Plant Growth and Development, Springer Science+Business Media Dordrecht Press, New York, pp. 339-355.

Supapvanich, S. 2015. Effects of salicylic acid incorporated with lukewarm water dips on the quality and bioactive compounds of rambutan fruit (Nephelium lappaceum L.). Chiang Mai Univ. J. Nat. Sci. 14(1): 23-37.

Terry, L. A. and D. C. Joyce. 2004. Elicitors of induced disease resistance in postharvest horticultural crops: A brief review. Postharvest Biol. Technol. 32: 1-13.

Wei, Y., Z. Liu, Y. Su, D. Liu and X. Ye. Effect of salicylic acid treatment on postharvest quality, antioxidant activities, and free polyamines of asparagus. J. Food Sci.76: 126-132.

Whangchai, K., K. Saengnil and J. Uthaibutra. 2006. Effect of ozone in combination with some organic acids on the control of postharvest decay and pericarp browning of longan fruit. Crop 
Prot. 25: 821-825.

Zhang, W. P., B. Jiang, L. M. Lou, M. H. Lu, M. Yang and J. F. Chen. 2011. Impact of salicylic acid on the antioxidant enzyme system and hydrogen peroxide production in Cucumis sativus under chilling stress. Z Naturforsch C. 66: 413-22.

Zhang, Y., K. S. Chen, S. L. Zhang and I. Ferguson. 2003. The role of salicylic acid in postharvest ripening of kiwifruit. Postharvest Biol. Technol. 28: 67-74 